\title{
Catherine Boone, Property and Political Order in Africa. Land Rights and the Structure of Politics
}

Jean-Pierre Jacob

\section{OpenEdition}

\section{Journals}

Édition électronique

URL : http://journals.openedition.org/anthropodev/449

DOI : 10.4000/anthropodev.449

ISSN : 2553-1719

Éditeur

APAD - Association pour l'anthropologie du changement social et du développement

Édition imprimée

Date de publication : 1 juillet 2016

Pagination : 181-186

ISBN : 797-10-93476-03-2

ISSN : 2276-2019

Référence électronique

Jean-Pierre Jacob, « Catherine Boone, Property and Political Order in Africa. Land Rights and the Structure of Politics », Anthropologie \& développement [En ligne], 44 | 2016, mis en ligne le 01 décembre 2016, consulté le 23 septembre 2020. URL : http://journals.openedition.org/anthropodev/449 ; DOI : https:// doi.org/10.4000/anthropodev.449

La revue Anthropologie \& développement est mise à disposition selon les termes de la Licence Creative Commons Attribution 4.0 International. 


\section{Property and Political Order in Africa Land Rights and the Structure of Politics}

Catherine Boone, New York, Cambridge University Press, 2014, 416 p.

Jean-Pierre Jacob

The colonial and postcolonial powers in Africa have in the past and continue today to allocate rights to land and natural resources to organize societies politically, using their territories strategically. In her wonderfully complex and well structured book, C. Boone reminds us that they are not unique in doing so, as the examples of the Ottoman Empire, USSR or China show. The author distinguishes from this point of view between two versions of these practices, echoing the old distinction between direct and indirect rule: on one side, neo-customary land tenure regimes, on the other, statist ones. These regimes are unevenly distributed, the former covering more space than the latter. Their frontiers don't match strictly countries or geographical entities. Although statist regimes are more frequent in East Africa than in West Africa, there are neocustomary enclaves in East Africa's countries as well as statist ones in West Africa.

A land tenure regime defines property rights, the authorities that manage these rights, the system of belonging that comes from their allocation ("citizenship rules") and the jurisdictions within which these rights apply. The big difference between the two regimes reside in the identity of these allocating authorities and their geographical location. By conscious design from the state ${ }^{1}$, in the neocustomary regime, local authorities, justified by some form of traditional legitimacy - usually based on autochtony - remain in charge. These local powers can be very diverse: familial, lineage or village elders (west Burkina Faso) or systems of local or regional chiefdoms (southern Ghana). Within the statist regime, it is the state that distributes the land rights, sometimes in a very direct manner, through some administrator, sometimes through politicians who want to reward their clients once they reach power, undoing former allocations made by rivals.

C. Boone specifies clearly the domain of validity of her analysis. Firstly, she states that her distinction between regimes is applicable to land tenure questions but cannot define the general governance of a given state. In Ghana, for instance, she notes that public institutions are at least formally open to rural populations except in the case of land tenure questions that are systematically referred to

1 "Land regimes are products of the state-making and institution-building strategies of modern state rulers, both colonial and postcolonial" (Boone, 2014: 315). 
customary chiefs. Secondly, she mentions that she is interested by social groups oriented toward household economy that obtain their land through neocustomary or statist authorities and excludes from her analysis actors that got their land through market and for cash crop production.

The hypothesis that structures the book follows at the same time a classical acknowledgement and a new line of questioning. She stresses that demographic pressures and land competition are the most important problem that shape land questions in contemporary Africa. They provoke, as Pauline Peters (2004, 2013) said, "a narrowing in the circle of belonging", i.e. a restriction imposed by authorities to the number of social groups susceptible to have access to land in a given jurisdiction. But C. Boone also insists on the fact that they don't constitute direct causations for the emergence of conflicts in the public sphere. For the author, there are huge differences in the possibility of public expression of disagreements and conflicts between countries and sometimes within countries and that these differences need to be related to the distinction she makes between land tenure regimes.

Within the neocustomary regime, autochtons are dominant and their relations with immigrants are ruled by the tutorat institution ${ }^{2}$. Under land pressure, autochtons sometimes want to take back the land allocated to immigrants to give it to their sons or to other farmers and, in doing so, they break the kind of mutual arrangements that were part of the tutorat rules. Eventhough this kind of practice has a very devastating impact on immigrants installed in an area sometimes since several generations, it doesn't lead often to open conflict because this type of event is managed by customary authorities and, as such, stay confined to the local scale. Within this type of context, there is no politicization of the claims. Lacking any means of resort to formal recourse, the late comers end up quietly leaving their zone of residence for another one, expected to be more favorable. The central state saves considerable time and energy in not having to deal with these kind of problems and politicians have no vested interest in engaging themselves in these matters.

In the statist land tenure regime, power relationships are reversed. It is late comers rights that are supported by the state and the first comers the ones living situations of deprivation. The state being at the center of the allocation of resources, it is also at the center of the claims and contestations. Conflicts are publicly expressed and easily find support within the context of political parties in compe-

\footnotetext{
${ }^{2}$ An institution that rules immigrant allocation of land rights in exchange for their political and economic incorporation within the local first comers' group (see Chauveau, 2006).
} 
tition. Peasants or herders living the same situations of dispossession associate themselves in large ethnic coalitions, to constitute strong pressure groups on the national scale, i.e. at the scale where contestations need to be expressed because that is where they are managed (the kalenjin case in Kenya being one of the more famous!).

Within the neocustomary regime, local citizenship categories are dominant and inform the way people manage their relationships in regard to land. Within the statist regime, it is national citizenship that is at stake and there are constant references to the right of every citizen to live wherever he chooses on the national territory.

The thesis is ambitious and better still, it is convincing. It gives meaning to hundreds of field observations spread within monographs and ethnographical articles. The author is a thorough researcher, who gathered an impressive corpus that entails a considerable number of studies in English and - more remarkable! - in French, sometimes taken from the most obscure grey literature. In total, the book analysis is substantiated by 32 regional case studies spread between 15 countries taken in the whole of Africa, a feature that is literally prodigious ${ }^{3}$ !

We would like to prolong and complement this rich analysis, on one point, which concerns neocustomary regimes and introduces the idea that, in these kinds of contexts, conflicts might also emerge between first comers themselves. As said before, demographic pressures and land competition are a general constraint and C. Boone concludes too quickly that this situation affects firstly immigrants and mainly immigrant agriculturalists, engaged like first comers in household economy, via the contestation of tutorat rules. She might have been influenced here by attempts to stress the symmetry of the systems she uncovered, classifying her two models of land tenure governance following the contrasting position that they give to same groups (first comers vs late comers). But in neocustomary regimes, migrants are not always the adjustment variable. Sometimes, first comers might have some good reasons to keep their tutorat relationships alive and well. In this case, conflicts emerge between autochtons. We need to engage the concept of space and of fractal positions to understand how they develop exactly.

C. Boone alludes to the diversity of the types of authorities that we encounter within this type of context (family, lineage, village elders, regional chiefs, see above) but she doesn't envision the possibility that, for a given regional space,

${ }^{3}$ Some comparative books on African land tenure do exist (see S. Joireman, 2011 or A.K. Onoma, 2010) but nothing of this width. 
several of these authorities could co-exist, ruling the allocation of rights at their jurisdiction's level. Actually, what is being managed at these different levels is less the allocation of rights than some form of regulation between land used as a private vs a common good, with a predominance of the latter to the former ${ }^{4}$. Private uses of land are necessary - there is no better system to stimulate production even from a "traditional" point of view - but not to the point of preventing collective objectives to be fulfilled using land (to settle late comers and make them participate in the aggrandizement of the community for instance). Our field studies in central-western Burkina Faso (see Jacob, 2007) show that there are three levels where the relationships between private vs common uses are managed:

- The regional level: a group of first comers' communities linked by a pact (they are under the same tutorat of a more ancient community, or tied by ritual or war alliances). Each village possessed its land but each land can be seen as constituting part of a territory "without limits" within which farmers - belonging to these allied communities - can freely circulate.

- The village level: a group of first comers' lineages that each has its own domain, these domains being seen from the point of view of local authorities as forming a single entity, usable for the realization of objectives that are in the higher interest of the collective (settling late comers, building a school or a health center...).

- The lineage or sub-lineage level: each autochtonous exploitation unit possesses parcels of land which also make up the common patrimony of a given lineage or sub-lineage.

What we see here are fractal situations where the same questions are dealt with at different levels. In these kinds of contexts, conflicts emerge between first comers but they emerge in an "orderly" manner, crystallizing first at the larger scale, where the sense of belonging might be eroded by the passing of time to slowly diffuse at the smaller scale, where people are the more likely to entertain multifunctional relationships that resist expression of discontent or opportunism. In other words, conflicts between first comers are likely to emerge at the "frontiers" between villages that are traditionally allied - and even more so between villages that didn't entertain such alliances, such cases do exist! - before manifestting themselves at lower levels, in a very literal illustration of P. Peters' (2004, 2013) remark about the process of "narrowing in the circle of belonging". At this larger level, they oppose individuals or groups who try to contest the notion of land

${ }^{4}$ Hence the fact that the bundle of private rights doesn't incorporate the right to sell. 
as an inter-community common good and to advance their own private interest, within a context where norms are often forgotten, regional customary authorities might have disappeared or are not considered legitimate anymore and the relationships between villages have been weakened by decades of "villagization" ${ }^{5}$.

Whatever the level where conflict emerges, it is explainable in the same terms: an individual or sub-group attempts to contest the power of the authorities in charge of the regulation of the relationships between land as a private vs a common good. When such an attempt succeeds, there is a displacement to the benefit of the contestants - at a lower scale then! - of said regulation power. We can see it neatly in examples drawn from center-west or south-west Côte d'Ivoire studied by J.-P. Chauveau (2006), which show how first comers' young leaders took over, in emergency contexts ${ }^{6}$, land resources that belonged to a village or a lineage to settle migrants and in doing so asserted their claims as tutors. These maneuvers were sometimes accepted or resisted, and when resisted, the conflicts opposed first comers' groups, over the question of who was in charge of the system's regulation and who should benefit from the tutorat rent (village or lineage elders and the young self-designed tutors). In the Burkinabè context outlined above, conflicts between first comers exhibit the same problems of confiscation and lack of public expression as the ones the author identifies in her analysis ${ }^{7}$. That is not automatically the case in Côte d'Ivoire which is characterized, in the areas mentioned

${ }^{5}$ By villagization, we don't mean the resettlement of entire populations that are specific to statist regimes (Ethiopia, Rwanda, Tanzania...) but this relentless public policy that insists on, from the colonial times to the "development" present, constituting villages as discreet entities, autonomous at the economic and administrative levels. As a consequence, villages stop being the "centers of themselves" as M. Akrich (1989) says, to become "localized".

${ }^{6}$ Pressures from the Houphouët-Boigny's regime to settle migrants at any rate.

${ }^{7}$ To complement C. Boone's analysis (see pages 107-108), in Burkina Faso the only conflicts that are given publicity are the ones that oppose herders to agriculturalists, because they often lead to killings and the destruction of encampments and, as a consequence, the mixing of state administration, journalists and politicians in the matters. It can be argued that herders are under some kind of de jure (pastoral areas carved out of agriculturalists domains by the state) or de facto (no tutorat relationships with local villages) statist regime. In any case, these dramatic cases suggest that herders don't benefit from a rarely mentioned advantage of tutorat relationships. If this institution doesn't ensure the rights to land for late comers under all circumstances, as C. Boone says (see above), they offer at least a protection from all offence against physical integrity. I have tried to explain elsewhere why this protection functioned only partially (for certain type of migrants but not for others) in the 2003-2011 crisis in Côte d'Ivoire (see Jacob, 2011). 
(center-west and south-west), and following C. Boone, by a statist allocation of rights.

\section{References}

AKRICH M., 1989, " De la position relative des localités. Systèmes électriques et réseaux socio-politiques ", Cahiers du Centre d'Etudes pour l'Emploi, 32 : 117-166.

CHAUVEAU J.-P., 2006, "How does an Institution evolve? Land, Politics, Intergenerational Relations and the Institution of the tutorat between autochtons and migrant farmers in the Gban region (Côte d'Ivoire)", in KUBA R., LENTZ C. (eds), Landrights and the Politics of belonging in West Africa, Leiden, Brill: 213-240.

JACOB J.-P., 2007, Terres privées, terres communes. Gouvernement de la nature et des hommes en pays winye (Burkina Faso), Paris, IRD Editions.

JACOB J.-P., 2011, « La terre comme droit de propriété intellectuelle et le travail comme grammaire commune dans les sociétés du Sud ", in LE MEUR P.-Y. et al. (dir.), Une anthropologie entre pouvoirs et histoire. Conversations autour de l'œuvre de Jean-Pierre Chauveau, Paris, IRD/Karthala : 583-601.

JOIREMAN S., 2011, Where there is no Government. Enforcing Property Rights in Common Law Africa, New York, Oxford University Press.

ONOMA A.K., 2010, The Politics of Property Rights Institutions in Africa, Cambridge, Cambridge University Press.

PETERS P., 2004, "Inequality and Social Conflict over Land in Africa", Journal of Agrarian Change, 4 (3) : 269-314.

PETERS P., 2013, "Conflicts over Land and Threats to Customary Tenure in Africa", African Affairs, 112 (449) : 543-562. 